\title{
Biomass Wastes: An Energy Option for Baja California, México
}

\author{
Gisela Montero1, Marcos A. Coronado1, Hector E. Campbell1, Jesus Cerezo1, \\ Alejandro A. Lambert ${ }^{2}$, Edgar E. Valenzuela ${ }^{2}$ \\ ${ }^{1}$ Instituto de Ingenieria, Universidad Autonoma de Baja California, Mexicali, México \\ ${ }^{2}$ Facultad de Ingenieria, Universidad Autonoma de Baja California, Mexicali, México \\ Email: gmontero@uabc.edu.mx
}

Received November 2013

\begin{abstract}
Cotton and wheat crops are essential part of the Baja California agricultural production. Such crops generate waste biomass after each harvest cycle, which is almost fully openly burned in order to clear land for the next cycle. Thus in the agricultural 2011 cycle, 542,000 tonnes of straw were generated from wheat in the Mexicali Valley. In addition, the residue from the cotton consisting of stalks exceeded 143,000 tonnes. All these residues are a source of energy that is discarded annually equivalent to $10.19 \mathrm{PJ}$. Therefore, in addition to determining the biomass potential available in the state from such wastes, the aim of this paper is to propose options for the use of the energy contained in the waste biomass considering the characteristics of raw material available and existing technologies. The results show that there is the potential to generate electricity with a system of $105 \mathrm{MW}$ of installed capacity, and also obtain annually 6.4 million liters of biodiesel. Obtaining this biofuel is by a transesterification reaction of waste vegetable oils, considering an average efficiency of $80 \%$ conversion, based on experimental results obtained with mixtures from Mexicali.
\end{abstract}

\section{Keywords}

Agricultural Biomass Wastes; Biodiesel; Electricity

\section{Introduction}

In line with the development of humanity, energy demand has increased causing the intensified use of waste as raw material for energy production in the world, as an alternative to meet part of the demand. Also, technologies have been developed and adapted based on the use of residual biomass, which can obtain liquid and gaseous fuels, heat, electricity [1]. In Mexico, biomass contributes to 3.8\% of primary energy, however, in this account only are considered sugarcane bagasse and wood and do not take into account other biomass resources from agricultural activities, considered as waste materials [2]. Such is the case of crop residues from cotton and wheat in the Mexicali Valley which are the main source of agricultural activities that support the regional economy.

In addition to these residues from agricultural activities in Baja California, the food preparation industry has as remnants the Waste Vegetable Oils (WVO), which were used in cooking and are usually sent to the municipal 
sewer system, thereby causing plugging problems, odors and pollution in general.

According to the results of the project entitled: "Potential and Feasibility of Using Bioethanol and Biodiesel for Transportation in Mexico”, biodiesel production from rapeseed, soybean, jatropha, sunflower, safflower, WVO and animal tallow, the feedstocks costs represent between $59 \%$ and $91 \%$ of biodiesel production costs and because of that, the WVO is an opportunity for biofuel production [3].

Considering these waste materials have a high energy content that can be processed for heat, electricity or fuel, in this work it was evaluated the options to transform agricultural waste, consisting of 543,000 and 143,000 t of wheat straw and cotton stalks respectively and 8 million liters of WVO, generated annually in Baja California by using proven technologies [4].

\section{Development}

Agricultural residues, considered in this assessment and available in Baja California are wheat straw and cotton stalks, which are generated annually after each harvest. In addition, there were the WVO generated in food preparation establishments.

\subsection{Technologies for Cellulosic Biomass Conversion}

Existing technologies for converting waste biomass into biofuel, thermal energy, electric or a combination of these, can be divided mainly into: combustion, gasification, pyrolysis and fermentation, as shown in Figure $\mathbf{1}$ [5].

Combustion is a thermo chemical process that takes place in the presence of oxygen and as a main product to obtain thermal energy from the conversion of the chemical energy contained in the processed material. This thermal energy is in turn used to generate steam and electricity.

Gasification involves the conversion of cellulosic biomass into synthesis gas, which can be converted into hydrogen, methane, alcohol mixture of liquid fuel via the Fischer-Tropsch synthesis, and other chemical compounds [6].

Pyrolysis is realized by thermal decomposition of biomass in the absence of oxygen. Depending on operating conditions may be obtained the so-called bio-oil or pyrolysis oil, synthesis gas $\left(\mathrm{H}_{2}\right.$ and $\left.\mathrm{CO}\right)$, tars and charcoal. Pyrolysis oil can be converted into diesel by hydrotreating and hydrocracking processes and to modify their properties so that it more suitable for use as a liquid fuel.

In fermentation a biochemical conversion is performed, i.e involving microorganisms such as yeasts aimed at

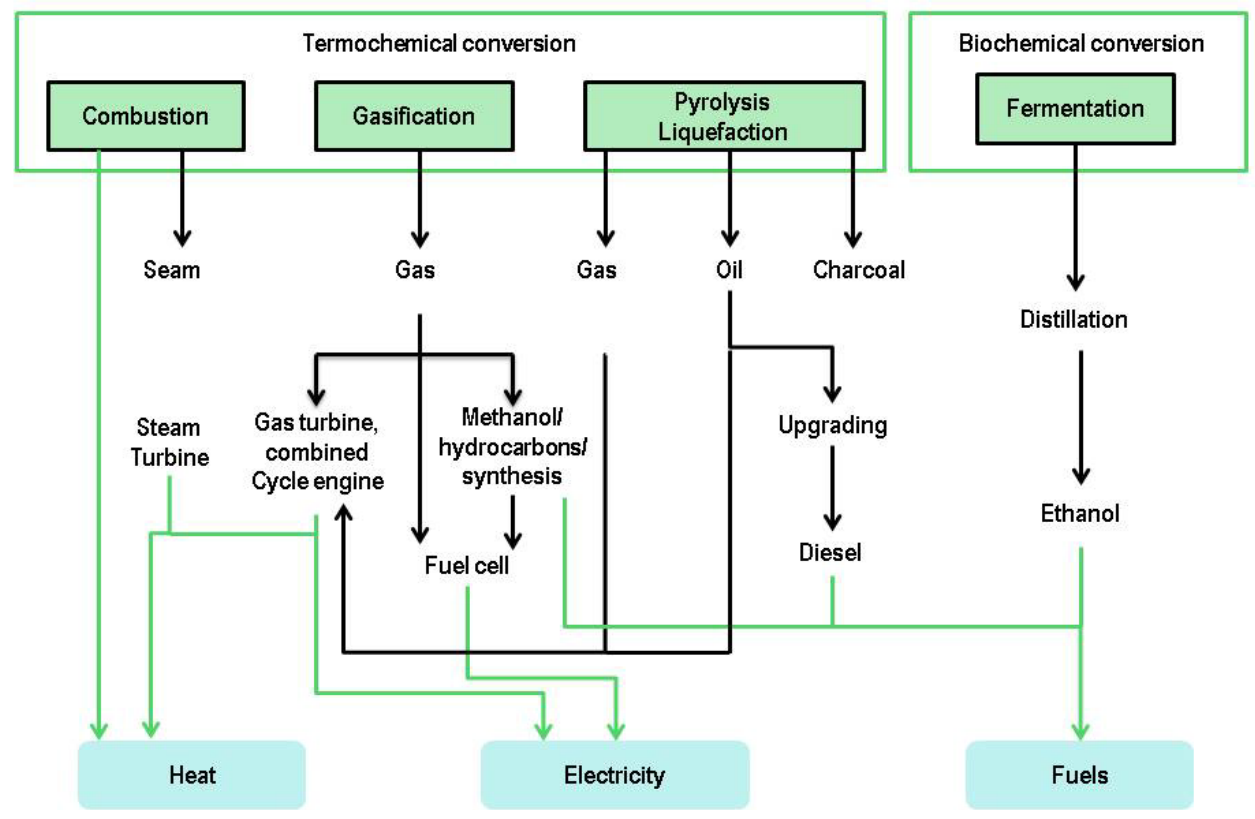

Figure 1. Technologies for cellulosic biomass conversion. 
converting organic matter into ethanol.

This process achieves the conversion of $50 \%$ to $60 \%$ of the feed stream and the remainder is a byproduct, which can be used as compost. In the case of cellulose, a pretreatment is necessary for hydrolysis to convert it into sugars that are subsequently fermented.

\subsection{Technologies for Vegetable Oil Conversion to Biodiesel}

The American Standard for Testing and Materials (ASTM) defines biodiesel as a mixture of mono- alkyl esters of long chain fatty acids, derived from vegetable oils or animal fats, and are used in compression - ignition engines. The processes for obtaining such esters differ essentially in the type of catalyst used and are named: acid catalyst, base catalyst, or a mixture of both and enzymatic catalyst, which are described below.

Alkaline catalyst. Is commonly used sodium hydroxide or potassium hydroxide with a short chain alcohol such as methanol or ethanol, as well as any type of vegetable oil. It is recommended to prepare the alkoxide in order to obtain a better overall efficiency of the reaction. Alkaline catalysed process is performed faster than the process with acid catalyst. Typical temperatures at which this reaction is performed is $60^{\circ} \mathrm{C}$ and is complete in about 1 hour.

Acid catalyst. In this method sulfuric or sulfonic acid is used, which catalyzes the reaction between the raw material composed of fatty acids and triglycerides (oil or fat) and methanol. In both types of catalysts, an excess of alcohol improves the conversion efficiency of triglycerides but glycerol recovery is more difficult. The typical reaction temperature is above $100^{\circ} \mathrm{C}$ and requires more than 3 hours for complete conversion.

Enzymatic catalyst. Catalysts used allow the transesterification of triglycerides, both in aqueous and non-aqueous systems. In this catalytic route, the free fatty acids present in the fat and WVO can be converted completely into alkyl esters. This represents an advantage over previous procedures. However, production costs in this way are greater than those for alkaline and acid catalyst [7].

Transesterification process. Glycerol is replaced by a simple alcohol such as methanol or ethanol, so as to produce methyl or ethyl esters of fatty acids.

The transesterification reaction can be represented as follows [8]:

$$
\mathrm{RCOOR}_{1}+\mathrm{R}_{2} \mathrm{OH} \longleftrightarrow \mathrm{RCOOR}_{2}+\mathrm{R}_{1} \mathrm{OH}
$$

trygliceride + alcohol $\leftrightarrow$ ester + glycerol

where in a simplified way: $\mathrm{R}$ = fatty acid chain; $\mathrm{R}_{1}=$ triglyceride chain and $\mathrm{R}_{2}=$ methyl or ethyl group.

\subsection{Biomass Resources in Baja California}

In 2011, the residue from the cotton cultivation in the Mexicali Valley, comprised by cotton stalks exceeded $143,000 \mathrm{t}[9,10]$. This was calculated considering a planted area of 32,461 ha, generation index of cotton stalks at 4.42 ton/ha [11] and a lower heat value (LHV) equal to $14.79 \mathrm{MJ} / \mathrm{kg}$ [12].

The wheat crop in 2011, reached 74,260 ha, with a rate of generation of straw at 7.3 t/ha [13]. It was considered a LHV of $17.5 \mathrm{MJ} / \mathrm{kg}$ [14] and that $85 \%$ of the straw generated in each agricultural cycle is burned in situ [15]. In relation to the WVO, and as a result of a research project of the Institute of Engineering, which was developed in an exploratory study, it was possible to make an estimate WVO generation of the Mexicali restaurant sector, which in 2010 totaled approximately 8 million liters per year [4]. Experiments were conducted using different samples of WVO and on average, 0.8 liters of biodiesel obtained per liter of WVO via alkaline processing.

\section{Results and Discussions}

\subsection{Energy Content of Waste Materials}

Figure 2 summarizes the results of the energy content of waste materials. The wheat straw and cotton stalks, show an energy balance of 10,105 TJ. While the WVO is potentially recoverable an annual amount of 206 TJ.

\subsection{Optional Uses for Biomass Resources of Baja California}

There are several commercially available technologies for the conversion of biomass through direct combustion 


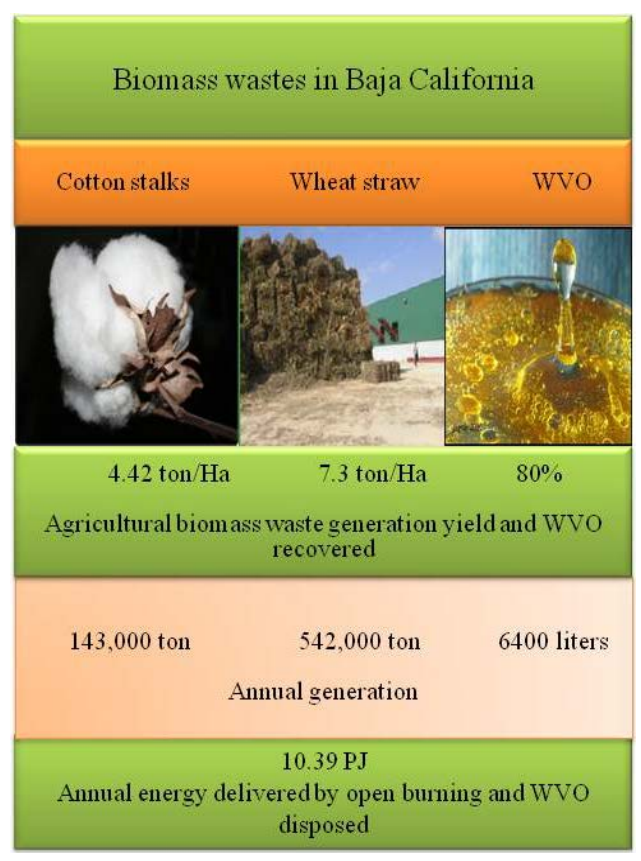

Figure 2. Energy potential of agricultural biomass waste.

for electricity generation. In the pyrolysis and gasification unlike direct combustion, biomass is raw material to produce a more valuable fuel (or heating power) which can be subsequently used in more specialized equipment and more efficient as called CHP (combustion heat and power).

These technologies converting biomass into higher value-added energy, involve higher cost of investment, operation and skilled labor. However, it is noteworthy that both technologies are capable of processing a wide variety of materials classified as waste, including hazardous.

For the generation of electricity by direct combustion of biomass is estimated that the best option is to distribute small independent modules. Also, it is highly recommended that the plant was constructed as close to the generation of biomass for avoiding transportation costs.

The fermentation was not considered as a relevant choice for this type of material because the lignocellulosic material must be previously hydrolyzed to convert sugars and then fermenting. However, such hydrolysis is complicated to put it into practice due to acidic media handling affecting performance of the bacteria used in the fermentation.

In relation to production costs, the reported values are from 3.8 to $10.2 \mathrm{c} / \mathrm{kWh}$ (U.S.) for a system whose technology is pyrolysis processing energy crops; $7.8 \mathrm{c} / \mathrm{kWh}$ (U.S.) for a gasifier is fed with low-cost plantations; $12.7 \mathrm{c} / \mathrm{kWh}(\mathrm{EU})$ for power generation by direct combustion of agricultural residues and 9.3 to $12.4 \mathrm{c} / \mathrm{kWh}$ (U.S.) for the case of electricity generation from straw combustion [16].

\section{Conclusions}

Considering the waste generated annually, Baja California can replace a significant fraction of fossil fuel consumption by using the energy contained in the waste biomass. This would increase the renewable energy share in the energy of Mexico.

The production of electricity from biomass is a competitive option compared to wind generation from the plant located in La Rumorosa. Besides agricultural residues considered in this assessment, it is advisable to include materials generated by other crops typical of Baja California. It is also very important that in addition to oleic wastes from restaurants be accounted for WVO generated at the household level and to contemplate alternatives for processing waste such as plastics, tires and hazardous waste generated in hospitals, which can be transformed materials with high added value and high energy through processes such as pyrolysis and gasification. 


\section{Acknowledgements}

The authors thank to the Universidad Autonoma de Baja California for its support to develop this research.

\section{References}

[1] Demirbas, F., Balat, M. and Balat, H. (2011) Biowastes-to-Biofuels. Energy Conversion and Management, 52, 18151828. http://dx.doi.org/10.1016/j.enconman.2010.10.041

[2] SENER (2010) Secretaría de Energía. Balance Nacional de Energía, 25.

[3] SENER (2006) Secretaría de Energía, Potencialidades y Viabilidad del uso del Bioetanol y Biodiesel para el Transporte en México.

[4] Coronado, M. (2010) Estudio de factibilidad de producción de energía a partir de aceite vegetal residual. Caso: Sector restaurantero. Tesis de maestría, Universidad Autónoma de Baja California, Mexicali.

[5] UNEP (2009) Converting Waste Agricultural Biomass into a Resource. Compendium of Technologies. The International Environmental Technology Centre. Osaka/Shiga, 441.

[6] Bain, R. (2012) The Task 33. Thermal Gasification of Biomass. International Energy Agency. http://128.131.132.12

[7] Meher, L., Sagar, V. and Naik, S. (2006) Technical Aspects of Biodiesel Production by Transesterification a Review. Renewable \& sustainable energy reviews, 10, 248-268. http://dx.doi.org/10.1016/j.rser.2004.09.002

[8] Zhang, Y., Dubé, M.A., McLean, D.D. and Kates, M. (2003) Biodiesel Production from Waste Cooking Oil: 1. Process Design and Technological Assessment. Bioresource Technology, 89, 1-16. http://dx.doi.org/10.1016/S0960-8524(03)00040-3

[9] SFA (2011) Anuario Estadístico de la producción Agrícola para el Estado de Baja California. http://www.sfa.gob.mx

[10] OEIDRUS (2012) Oficina Estatal de Información para el Desarrollo Rural Sustentable. Portal OEIDRUS Baja California. http://www.oeidrus-bc.gob.mx/oeidrus_bca/

[11] Gemtos, T. and Tsiricoglou, T. (1999) Harvesting of Cotton Residue for Energy Production. Biomass and Bioenergy, 16, 52. http://dx.doi.org/10.1016/S0961-9534(98)00065-8

[12] Domaiski, E. and Milne, T. (1986) Thermodynamic Data for Biomass Conversion and Waste Incineration. http://www.nrel.gov/biomass/pdfs/2839.pdf

[13] SFA (2012) Secretaría de Fomento Agropecuario. http://www.oeidrus-bc.gob.mx/oeidrus_bca

[14] McKendry, P. (2002) Energy Production from Biomass (Part 1): Overview of Biomass. Bioresource Technology, 83, 37-46. http://dx.doi.org/10.1016/S0960-8524(01)00118-3

[15] Moncada, A. and Quintero, M. (2008) Contaminación y control de las quemas agrícolas en Imperial, California, y Mexicali, Baja California. Región y Sociedad, XX, 3-24.

[16] Evans, A., Strezov, V. and Evans, T. (2010) Sustainability Consideration for Electricity Generation from Biomass. Renewable and Sustainable Energy Reviews, 14, 1419-1427. http://dx.doi.org/10.1016/j.rser.2010.01.010 